\title{
JUDICIAL POWER AND "THE POLITICS OF THE PEOPLE"
}

\author{
LOUIS H. POLLAKं
}

SINCE several of his senior brethren devoted well over one hundred and fifty pages of the United States Reports to discussing the issues thought to be presented in Baker v. Carr, Mr. Justice Stewart can hardly be charged with garrulousness in claiming two pages more. The central thrust of his concurring opinion was to remind the nation what it was the Supreme Court had explicitly decided and the limited character of that decision:

The Court today decides three things and no more:

"(a) that the court possessed jurisdiction of the subject matter; (b) that a justiciable cause of action is stated upon which appellants would be entitled to appropriate relief; and (c) ... that the appellants have standing to challenge the Tennessee apportionment statutes." 1

Rendered into ordinary English, the Court's holding apparently came to this:

Appellants are Tennessee citizens eligible to vote for members of the General Assembly. Pursuant to the sixty-year old Tennessee apportionment formula, the voting districts to which appellants belong are-so appellants allege-allotted significantly fewer representatives in the Assembly than other voting districts of comparable population. In a great many instances, the alleged differences in representation seem to correspond with differences in the character of the voting districts, in the sense that predominantly rural districts fare far better than predominantly urban districts. (But it also appears-as Mr. Justice Clark observes in his concurring opinion - that the apportionment formula "discriminates horizontally, creating gross disparities between rural areas themselves as well as between urban areas themselves. ... ."2) Under-representation in the General Assembly means that appeliants, and those similarly situated, are disadvantaged in that they have, voter for voter, markedly less influence on state policy than voters in more favored districts.

In the face of a motion to dismiss, the alleged disparities in voting strength-initially the product of state legislative action, and thereafter perpetuated by state legislative inaction-must be assumed to exist. Disparity in treatment at the hands of state officials is not, of itself, actionable. But where the complaint adequately recites: (1) that disparity in treatment works significant disadvantage; and (2) that the basis for the disparate treatment is either (a) simply irrational, or (b) based on value preferences not open to a state to indulge in; then the complaint states a case under the equal protection clause of the Fourteenth Amendment and is, in consequence, good against a motion to dismiss. And so here the judgment of dismissal is reversed and the case is remanded for trial.

$\dot{\mathrm{i}}$ Professor of Law, Yale Law School.

1. Baker v. Carr, 369 U.S. 186, 265 (1962).

2. Id. at 256. 
If this is a fair exposition of what the Court meant in Baker v. Carr, why did the dissenters regard it as such radical doctrine? What made the decision, in Mr. Justice Frankfurter's words, "a massive repudiation of the experience of our whole past ...."? And was the Court really "asserting destructively novel judicial power. ..."? ?4

Certainly Baker v. Carr opens up unfamiliar judicial vistas. It signifies a sharp increase in judicial readiness to inquire into the architecture of the legislative establishment-certainly at the state, and perhaps even at the congressional, level. In announcing its readiness to inquire the Court has deliberately disengaged itself from doctrines which, starting with Colcgrove v. Green ${ }^{5}$ in 1946, had prevailed for the fifteen years prior to Baker v. Carr. In Colegrove the Court had declined to examine the marked discrepancies in population between Illinois' urban and rural congressional districts. Thereafter, in 1948, the Court refused to disturb an Illinois statute which barred new political parties from the state-wide ballot unless they could recruit 25,000 adherents, including a minimum of 200 in at least 50 of the state's 102 counties, notwithstanding the vast population differences between Chicago's Cook County, which has over half the state's registered voters, and the down-state, rural counties. ${ }^{6}$ And in 1950 the Court was unmoved by an attempt to test the "county unit" system governing the Georgia primaries (Georgia's only meaningful elections) ${ }^{7}$ under which the winner of each county's popular vote received that county's entire "county unit," the units being allocated among the counties by a formula which enormously inflated the sparsely populated rural counties at the expense of counties embracing dense urban centers such as Atlanta. ${ }^{8}$

Underlying these decisions not to inquire further were two judicial themes. One sounded like a proposition of substantive constitutional law :

It would be strange indeed, and doctrinaire, for this Court, applying such broad constitutional concepts as due process and equal protection of the laws, to deny a State the power to assure a proper diffusion of political initative as between its thinly populated counties and those having conr centrated masses, in view of the fact that the latter have practical opportunities for exerting their political weight at the polls not available to the former. ${ }^{9}$

The other was an assertion of the inappropriateness of judicial inquiry:

[T] his controversy concerns matters that bring courts into immediate and active relations with party contests. From the determination of such issues

3. Id. at 267.

4. Ibid.

5. 328 U.S. 549 (1946).

6. MacDougall v. Green, 335 U.S. 281 (1948).

7. Cf. Smith v. Allwright, 321 U.S. 649 (1944) ('Texas); United States v. Classic, 313 U.S. 299 (1941) (Louisiana); Rice v. Elmore, 165 F.2d 387 (4th Cir. 1947), ccrt. denied, 333 U.S. 875 (1948) (South Carolina).

8. South v. Peters, 339 U.S. 276 (1950).

9. MacDougall v. Green, 335 U.S. 281, 284 (1948). 
this Court has traditionally held aloof. It is hostile to a democratic sy'stem to involve the judiciary in the politics of the people. And it is not less pernicious if such judicial intervention in an essentially political contest be dressed up in the abstract phrases of the law. * * Courts ought not to enter this political thicket. The remedy for unfairness in districting is to secure State legislatures that will apportion properly, or to invoke the ample powers of Congress. ${ }^{10}$

The two judicial themes worked together to justify abstention.

This was the judicial strain which the Court, in Baker v. Carr, declined to follow. But it is not quite accurate to say that the Court thereby broke wholly new ground. For there is another, and a longer, line of cases, some of recent vintage, in which the Court took it upon itself to "enter [a] political thicket." To be sure, the cases announcing the right of Negroes to participate equally with whites in the southern electoral process-the cases starting with Nixon v. Herndon, 11 running through the "white primary" cases, Snith v. Allzeright, ${ }^{12}$ and Terry $v$. Adams, ${ }^{13}$ and culminating two terms back in Gomillion v. Lightfoot, ${ }^{14}$ which challenged Alabama's attempted mutilation of the City of Tuskegee-involve another sort of "political thicket." But even if this different sort of thicket inhabits another part of the constitutional forest, isn't it the same forest? Or is this thicket, as the dissenters in Baker v. Carr suggest, a rara arbor growing at some wholly isolated level of constitutional discourse?

Mr. Justice Frankfurter was the author of the Court's opinions in Colegrove and in Gomillion. For him (and for Mr. Justice Harlan, who joined his Baker v. Carr dissent), the irrelevance of the Negro disenfranchisement cases to the problems posed in Baker v. Carr was plain:

The cases involving Negro disfranchisement are no exception to the principle of avoiding federal judicial intervention into matters of state government in the absence of an explicit and clear constitutional imperative. For here the controlling command of Supreme Law is plain and unequivocal. An end of discrimination against the Negro was the compelling motive of the Civil War Amendments. The Fifteenth expresses this in terms, and it is no less true of the Equal Protection Clause of the Fourteenth. 15

With a portion of this analysis there can be no quarrel. Of course it is true that " $[a] n$ end of discrimination against the Negro was the compelling motive of the Civil War Amendments." But it is also true that the equal protection

10. Colegrove v. Green, 328 U.S. 549, 553-54, 556 (1946). The reference to congressional power in Colegrove presumably relates to the fact that the malapportionment there challenged was in Illinois' congressional districts; possibly Congress could also cope with cognate vices whose impact is confined to non-federal elections by invoking its power to enforce the fourteenth amendment and/or its article IV obligation to guarantec to each state a republican form of government.

11. 273 U.S. 536 (1927).

12. 321 U.S. 649 (1944).

13. 345 U.S. 461 (1953).

14. 364 U.S. 339 (1960).

15. 369 U.S. at $285-86$. 
clause has been found applicable to a whole host of other invidious or irrational discriminations. However, the Baker v. Carr dissenters regard governmental discrimination against Negroes as peculiarly deserving of judicial scrutiny because, in the fourteenth as well as in the fifteenth amendment, "the controlling mandate of the Supreme Law is plain and unequivocal." Judicial recognition of the fourteenth amendment's primary purpose, and judicial commitment to fulfill that purpose in vigorous fashion, are of course highly appropriate. And the appropriate corollary of that recognition and commitment is that, as against challenges to other forms of official discrimination, a challenge to state-imposed disabilities attaching to Negroes, qua Negroes, is the easiest sort of equal protection case to frame. But isn't that as far as the distinction should carry? Surely the fact that the constitutional mandate is plainer and less equivocal in an instance of anti-Negro discrimination than in others doesn't make such a claim more justiciable than other equal protection claims; it simply makes a justiciable law suit easier to win.

It may well be that the framers of the fourteenth amendment anticipated congressional, not judicial, enforcement of its commands. So much, at all events, seems indicated by Professor Alexander M. Bickel's researches. ${ }^{10}$ But the Supreme Court early assumed major responsibility for enforcing the amendment, and not only in instances of anti-Negro discrimination. It is not entirely clear, therefore, what logic would support a double standard of justiciability, under which the federal courts would process all equal protection cases except those in the realm of suffrage, and in that one realm would find that only a complaint challenging anti-Negro discrimination could rise to the dignity of a "case" or "controversy."17

Actually, it is none too clear that the Baker v. Carr dissenters really meant to insist on so narrow a canon of justiciability in voting cases. Thus, they found it sufficient that Baker v. Carr was

... not a case in which a State has, through a device however oblique and sophisticated, denied Negroes or Jews or redheaded persons a vote, or given them only a third or a sixth of a vote. That was Gomillion $v$. Lightfoot .... What Tennessee illustrates is an old and still widespread method of representation - representation by local geographic division, only in part respective of population-in preference to others, others, forsooth, more appealing. Appellants contest this choice and seek to make this Court the arbiter of the disagreement. They would make the Equal Protection Clause the charter of adjudication....18

16. Bickel, The Original Understanding and the Segregation Decision, 69 HAnv, L. Rev. 1, 64 (1955).

17. Distinctions taken between cases arising under the fourteenth amendment and those arising under the fifteenth will not support such a double standard. Smith v. Allwright, Terry $v$. Adams and Gomillion v. Lightfoot seem to have been decided under the latter amendment, but Nixon v. Herndon and Nixon v. Condon, 286 U.S. 73 (1932), were fourteenth amendment cases. See Pollak, Racial Discrimination and Indicial In:tegrity: A Reply to Professor Wechsler, 108 U. PA. L. REv. 1, 22 (1959).

18. 369 U.S. at 300. 
The dissenters seem to have been saying that a complaint charging the diminution of the voting rights of Jews, qua Jews, or redheaded persons, qua redheaded persons, would have stated a justiciable claim. But why so? Confining the franchise to Gentiles (or Protestants) has not been a significant aspect of our political arrangements for a century-and-a-half ; but it is assuredly an "old" -one might even say a rational-_"method of representation."10 Disenfranchising, or qualifying the franchise, of redheaded people would seem a novel, and prima facie irrational, "method of representation" (although in all likelihoodunless achieved by a Gomillion-type subterfuge-it would be adopted as a state policy only after some attempt at demonstration of the reasonableness of the proposed distinction ${ }^{20}$ ). But if these are cases in which the Supreme Court could serve as "the arbiter of the disagreement" and use "the Equal Protec-. tion Clause as the charter of adjudication," what touchstone of justiciability should cause the Court to stay its hand from ordering a trial in Baker $v$. Carr?

Does not the answer lie elsewhere than in a quest for standards of justiciability? Does not the answer lie in the dissenters' apparent view that on the merits, taking their complaint at full value, the appellants in Baker $v$. Carr should not prevail? Were not the dissenters really resolving the justiciability question by reference to the Court's prior reading of the equal protection clause as a concept which did not "deny a State the power to assure a proper diffusion of political initiative as between its thinly populated counties and those having concentrated masses ...." ? ${ }^{21}$

Mr. Justice Brennan's majority opinion in Baker v. Carr did not reject this constitutional generalization. And each of the three concurring opinions-that of Mr. Justice Douglas, that of Mr. Justice Clark, and that of Mr. Justice Stewart-was at pains to deny that the equal protection clause required that every vote cast in a state election have an arithmetical impact equal to every

19. Prior to the Revolution, many of the colonies denied the vote to Jews. PFefrer, Church, State and Freedox 80 (1953); Wruliasrson, Asrerican Suffrage fross Property to Democracy 1760-1860 16 (1960). The constitutions adopted contemporancous$1 y$ with the Revolution, and practice thereunder, tended generally to a more liberal view of eligibility to vote. See id. at 115 . But some elements of religiously oriented politial disability lingered on. Section 10 of the Pennsylvania Constitution of 1776, in force until 1790, required members of the state legislature to acknowledge "the Scriptures of the Old and New Testament to be given by Divine inspiration." 5 Thorpe, Asserrcar Criarters, Constitutions and Organic Laws 3085. Article XXXII of the North Carolina Constitution of 1776 denied public office to anyone unwilling to acknowledge "the being of God or the truth of the Protestant religion, or the divine authority either of the Old or New Testaments...." Id. at 2793. In 1835, the word "Christian" was substituted for "Protestant." Id. at 2798-99. In fact, however, a Jew was seated in the North Carolina Legislature in 1808 without substantial difficulty. PFEFFER, op. cit. supra at 126.

20. Cf. Skinner v. Oklahoma, 316 U.S. 535 (1942). Compare Putrins, Rnce Ard REASON-A YANKEE VIEW (1961), an obnoxious, pseudo-scientific attempt to justify the continued segregation of Negroes.

21. MacDougall ఛ. Green, 335 U.S. 281, 284 (1948). 
other vote cast. ${ }^{22}$ And yet the majority remanded the case for trial. Why? Quite obviously because acquiescence in the generalization that a state can so relate geography and voting strength as "to assure a proper diffusion of political initiative" can hardly be taken as acquiescence in the proposition that any geographic "diffusion of political initiative" is a "proper" one.

The dissenters in Baker v. Carr observed that, "Appellants invoke the right to vote and to have their votes counted. But they are permitted to vote and their votes are counted."23 Is it obtuse to read into this observation a concession that a justiciable controversy would be presented if a state's plan for "diffusion of political initiative" denied all, or even some, urban communities any voice in state-wide elections? Would not such a limitation on the suffrage, properly alleged in a complaint, pose for the Supreme Court a justiciable question as to the reasonableness of the limitation, just as in the past the Court has inquired into the reasonableness of conditioning the right to vote on payment of a poll tax ${ }^{24}$ or satisfaction of a literacy test ${ }^{25}$ And if blanket foreclosure of the vote in urban constituencies would pose a justiciable question, why would courts be unable to make a comparable inquiry into arrangements which let the urbanite cast his ballot but which accorded that ballot only a tenth or a hundredth the value of the ballot cast by his country cousin?

Mr. Justice Frankfurter and Mr. Justice Harlan have indicated that under the decided cases there is no "constitutional limitation upon the relative weight to which the law might properly entitle respective ballots, even in federal elections." 26 But how can such a proposition of constitutional law have intelligible content across the board, without examination of the particular community patterns which might lead a particular state to fashion particular allocations of voting strength? Perhaps the polity which is Georgia can adduce reasons for restraining cold-eyed urban domination adequate to explain the gross disparities in voting strength apparently embodied in its "county unit" system. ${ }^{27}$ Yet the Court spared Georgia that task when first the system was attacked, apparently preferring to validate any and all disparities as reflecting what it had theretofore called "a proper diffusion of political initiative."28 But surely it

22. 369 U.S. at 244-45 (Mr. Justice Douglas); id. at 258 (Mr. Justice Clark); id. at 265-66 (Mr. Justice Stewart).

23. 369 U.S. at 299. By way of footnote, the dissenters added, inter alia, that previous decisions "do not so much as suggest that there exists a constitutional limitation upon the relative weight to which the law might properly entitle respective ballots, even in federal elections." Id. at 299 n.32.

24. Breedlove v. Suttles, 302 U.S. 277 (1937).

25. Lassiter v. Northampton Election Bd., 360 U.S. 45 (1959); cf. Davis v. Schnell, 81 F. Supp. 872 (S.D. Ala. 1948), aff'd, 336 U.S. 933 (1949).

26. See note 23 supra.

27. See South v. Peters, 339 U.S. 276, 278 (1950) (dissenting opinion) for a recital of the asserted inequalities inherent in the "county unit" system.

28. In South v. Peters, 339 U.S. 276 (1950), the Court affirmed dismissal of the complaint, citing Colegrove v. Green, 328 U.S. 549 (1946), and MacDougall v. Green, 335 U.S. 281 (1948). It was in the latter case that the Court referred to the state's undoubted "power to assure a proper diffusion of political initiative ...." Id. at 284. 
is not beyond the wit of judges to fashion a rough calculus for measuring officially ordained disparities in voting strength against the assigned justification, as the Court now will apparently have to do in a new "county unit" case coming before it."29 Or, in Baker v. Carr itself, perhaps Tennessee can on remand justify (as it has not seriously attempted to do thus far) not only the broad pattern of urban-rural variance but the further fact, adverted to by Mr. Justice Clark, that Tennessee's system "discriminates horizontally, creating gross disparities between rural areas themselves as well as between urban areas themselves...."

To have continued to dispense with inquiry-to have continued to float the postulate that any disparities are sound ones-would have perpetuated a trivialization of the equal protection clause. Correlatively, to have continued to deny the competence of judges to evaluate the reasonableness of these kinds of community choices seems inconsistent with the trust Americans customarily repose in their judiciary to construct rules of reason delimiting other fundamental community choices, including choices in the realm of voting rights. ${ }^{31}$

29. Suggestions as to some of the forms this judicial calculus may tatie are contained in Professor Thomas I. Emerson's thoughtful study in this symposium: Malopporfionment and Judicial Power, 72 Y ALE L.J. 64 (1962).

The new "county unit" case is Gray v. Sanders, No. 959, October Term, 1961, probable jurisdiction noted, 30 U.S.L. WeEk 3391 (June 18, 1962). The New York Times, Sept. 30,1962, p. 74, col. 3 , reported the case as follows:

A three-judge Federal District Court tossed out the unit system in the decision to be reviewed by the Supreme Court. In the popular vote primary-the first in this century - a moderate, urban candidate, Carl E. Sanders, won the Democratic nomination for Governor, tantamount to election.

And, after the unit system was abandoned for Congressional primaries, too, a 34-year old Atlantan, Charles L. Weltner, ousted a long-time segregationist, Representative James C. Davis. Mr. Davis would have won in unit voles.

30. 339 U.S. at 256. This sort of horizontal disparity is also not unique. In Connecticut, for example, the 10th Senatorial District in New Haven has less than half the population of the 8th and 9th Districts in the same city, and less than a third the population of the 1st District in Hartford. New Haven Register, Aug. 19, 1962, see 2, p. 2, cols. 3-4.

31. If a case like Baker v. Carr were denominated "political" because it "concerns matters that bring courts into immediate and active relations with party contests," Colegrove v. Green, 328 U.S. 549, 553 (1946), the same could be said of cases testing poll taxes and literacy qualifications: partisan conflicts between farmer and city dweller are in the American grain, but so too are those between creditor and debtor classes, and (as is suggested by the current controversy over the disenfranchisement of thousands of New York's Puerto Ricans) between native Americans and newcomers not yet literate in English. Mr. Madison made all this abundantly clear long ago, in Tue Feozrnust No. 10. See note 36 infra and the excerpt quoted in the text at that point.

Elaborate inquiry into whether the issues posed in Baker $\%$. Carr are within the ambit of article IV's guarantee of a republican form of government seems almost beside the point. The guarantee clause can be readily understood as a grant of power to Congress and the President; it need not be turned into a withdrawal of power from the judiciary. The problem in Baker $v$. Carr was not whether the "political" branches could ast, but whether in the absence of action by them (except in the sense that the Solicitor General appeared as amicus curiae on appellants' side of the case), the judiciary could not perform its ordinary responsibility of enforcing the equal protection clause. 
There are, as the dissenters in Baker $v$. Carr insisted, some things wrong with the United States that judges cannot put to rights. The dissenters felt that the problem of malapportionment belongs in that category: "In this situation, as in others of like nature, appeal for relief does not belong here. Appeal must be to an informed, civically militant electorate. In a democratic society like ours, relief must come through an aroused popular conscience that sears the conscience of the people's representatives." 32 But the very heart of the problem is that the incumbent elective officials who have the power to make or block remedial laws are themselves not "the people's representatives." They are the faithful servants of muscular minorities whose continued control over stateand (though to a lesser extent) national-policy depends upon and will insure eternal viligance against encircling majorities and eternal frustration of their attempted reforms. ${ }^{33}$ If the Court in Baker v. Carr had affirmed dismissal of the complaint, the Court would in effect have declared that the only power to arrest the pervasive systemic disorder of malapportionment lay in the hands of those who thrive upon the malady. And this would have been an ominotis declaration, for the malady is a grave one, a sclerosis which clogs the lawmaking heart of the American body politic.

For what is at stake is the central integrity of the governmental mechanisms the American people adopted as the means of carrying out the American experiment. The American people wrote into their Constitution a design for a new national government, tripartite in form; they also wrote into their Constitution the expectation that the constituent states would maintain their republican institutions through state governments likewise tripartite in form. ${ }^{\text {d4 }}$ This is not to say that the Constitution postulated identical governmental structures at national and state levels. ${ }^{35}$ It is to say that at each level the Constitution postulated the idea of a judiciary, the idea of an executive, andat the heart of government-the $i d e a$ of a legislature. They espoused the principle of a representative law-making branch, and they did so deliberately, knowing its dangers :

No man is allowed to be a judge in his own cause, because his interest would certainly bias his judgment, and, not improbably, corrupt his in-

32. 369 U.S. at 270 .

33. One of the oft-repeated objections to the American system of judicial review is, of course, that it saps legislators of the instinct for constitutionalism which would flourish if their power to make laws were unreviewable. But the history of the malapportionment problem in general, and the particular Tennessee history (of blithe disregard for Tennessee's own constitutional mandate to reapportion at regular intervals) which culminated in Baker v. Carr, offer little evidence to support the suggestion that legislators freed of judicial supervision would grow into man-sized and responsible participants in the processes of government.

34. U.S. Const., art. I, secs. 2, 3, 4; art. II, sec. 1 ; art. IV, secs. 3, 4; arts. V \& VI.

35. Or even that the three branches of state governments must maintain the precise distribution of functions prescribed by the Constitution on the national level. Dreyer v. Illinois, 187 U.S. 71, 84 (1902) ; cf. Sweezy v. New Hampshire, 354 U.S. 234, 256-57 (1957) (concurring opinion); and see Pollak, Mr. Justice Frankfurter: Judgment and the Fourteenth Amendment, 67 YALE L.J. 304, 314 (1957). 
tegrity. With equal, nay with greater reason, a body of men are unfit to bo both judges and parties at the same time; yet what are many of the most important acts of legislation, but so many judicial determinations, not indeed concerning the rights of single persons, but concerning the rights of large bodies of citizens? And what are the different classes of legislators but advocates and parties to the causes which they determine?...

It is in vain to say that enlightened statesmen will be able to adjust these clashing interests, and render them all subservient to the public good. Enlightened statesmen will not always be at the helm. Nor, in many cases, can such an adjustment be made at all without taking into view indirect and remote considerations, which will rarely prevail over the immediate interest which one party may find in disregarding the rights of another or the good of the whole.

The inference to which we are brought is, that the causes of faction cannot be removed, and that relief is only to be sought in the means of controlling its effects. ${ }^{36}$

One of the beneficent devices for "controlling its effects" which the people of the United States ultimately fashioned was the equal protection clause. As Mr. Justice Jackson remarked:

Invocation of the equal protection clause does not disable any governmental body from dealing with the subject at hand. It mercly means that the prohibition or regulation must have a broader impact. I regard it as a salutary doctrine that cities, states and the Federal Government must exercise their powers so as not to discriminate between their inhabitants except upon some reasonable differentiation fairly related to the object of regulation. This equality is not merely abstract justice. The framers of the Constitution knew, and we should not forget today, that there is no more effective practical guaranty against arbitrary and unreasonable government than to require that the principles of law which officials would impose upon a minority must be imposed generally. Conversely, nothing opens the door to arbitrary action so effectively as to allow those officials to pick and choose only a few to whom they will apply legislation and thus to escape the political retribution that might be visited upon them if larger numbers were affected. Courts can take no better measure to assure that laws will be just than to require that laws be equal in operation. ${ }^{37}$

To insist "that laws be equal in operation," by uprooting those which are not, is a prudent exercise of judicial power. It also seems prudent to take those prophylactic measures which will minimize legislative tendencies to enact laws of a different kind. To require states, and the United States, to conform their legislative structures more closely to the idea of a legislature is such a measure. Baker v. Carr should expedite the process.

36. The Federalist No. 10, at 56-57 (Earle ed. 1937) (Madison).

37. Railway Express v. New York, 336 U.S. 106, 112-13 (1949) (concurring opinion). 